\title{
Commentary on sentinel lymph node identification with technetium-99m tin colloid in non-small cell lung cancer
}

Michael J. Liptay, MD

See related article on page 486 .

From the Section of Thoracic Surgery, Evanston Northwestern Healthcare, Evanston, Ill.

Received for publication April 23, 2002; accepted for publication May 10, 2002.

Address for reprints: Michael J. Liptay, MD, Head, Section of Thoracic Surgery, Evanston Northwestern Healthcare, Burch 100, 2650 Ridge Ave, Evanston, IL 60201 (E-mail: m-liptay@nwu.edu).

J Thorac Cardiovasc Surg 2002;124:428-30

Copyright () 2002 by The American Association for Thoracic Surgery

0022-5223/2002 \$35.00+0 $\quad \mathbf{1 2 / 1 / 1 2 6 8 1 4}$

doi:10.1067/mtc.2002.126814 
stage tumors. Those patients with adenopathy and bulky tumors will more than likely have multiple involved nodal stations.

Nomori and colleagues ${ }^{9}$ also noted that patients with chronic obstructive pulmonary disease were less likely to have identifiable sentinel nodes with their technique. One possible explanation would be an attenuation of lymphatics along with the loss of alveoli and functional lung tissue seen with emphysema. Further study will elucidate whether these patterns continue.

\section{Intraoperative Versus Preoperative Technique}

In Japan the use of radioisotopes is strictly limited to designated areas. The intraoperative injection technique is impractical in this environment. The benefits of preoperative tumor injection the night before include better logistical coordination with nuclear medicine and radiation safety issues and the ability to perform preoperative imaging to plan surgery. These are balanced by the patient requiring a separate procedure with the small but real risks of pneumothorax, bleeding, and tumor seeding of the needle tract. Which technique will ultimately be used is unclear, as currently available data show both to have reasonable sentinel node detection rates.

\section{"Skip Metastases"}

Mediastinal lymph node involvement without concurrent spread to the intraparenchymal and hilar nodal basins has been termed "skip metastasis," The incidence of this phenomenon in patients with positive $\mathrm{N} 2$ mediastinal nodes has been reported to be between $20 \%$ to $30 \%$ in most series. ${ }^{10}$ Recent studies have attempted to distinguish between patients with skip N2 metastases and those with traditional N1 and $\mathrm{N} 2$ positive findings by arguing that patients with the skip pattern have a prognosis similar to that of patients with stage II (N1) rather than stage III (N2) disease. ${ }^{11}$ New data suggest that the nearly 40,000 patients with stage III locoregionally advanced disease have a wide variation of prognoses within the same stage. ${ }^{11}$ The sentinel node technique may allow better understanding of common drainage patterns of different tumor locations. This may lead to improved prognostic separation of patients based on the number and degree (gross/micrometastatic) of nodes involved. The impact on overall prognosis, therapeutic decision-making, and new staging systems remains to be determined.

Nomori and colleagues ${ }^{9}$ reported 14 of 40 sentinel nodes as mediastinal. Their ability to identify these in vivo was highly accurate $(88 \%)$. Although the sentinel node technique may not ever be used to stratify those requiring a full mediastinal node dissection from a sampling or no dissection, the information gained from detailing the actual nodal drainage of each tumor will continue to blur the lines between $\mathrm{N} 1$ and $\mathrm{N} 2$ disease, calling for a reconsideration of the staging of single site skip pattern metastases.

\section{Micrometastases/Ultrastaging}

Nomori's group ${ }^{9}$ found no micrometastases in the 26 sentinel nodes classified as negative by standard histologic evaluation. The authors report performing additional 3-step sections and immunohistochemistry with cytokeratin antibodies. This is in contrast to our recent report ${ }^{7}$ detailing results in our first 100 patients in which 7 patients were upstaged with the identification of micrometastatic disease in the sentinel nodes. We performed serial sections at $30-\mu \mathrm{m}$ intervals (average 10 per slide) as well as cytokeratin antibody staining.

With the increasing availability of real time reverse transcriptase-polymerase chain reaction analysis and other even more sensitive techniques to identify single cell nodal metastases, the future role of sentinel node identification in directing these examinations to the most likely site for metastases remains promising. Likewise molecular staging techniques may become more prognostically important as more specific markers and patterns are identified. ${ }^{12}$ The partnering of more precise sentinel node identification with more sensitive and informative ultrastaging molecular techniques will likely revolutionize the way we stage lung cancer and decide on appropriate postoperative treatment plans.

Currently, conflicting data exist to support the administration of chemotherapy for localized completely resected lung cancer, although clinical trials continue to investigate this intervention. If improvements in systemic therapy are forthcoming, more accurate or "ultrastaging" techniques may assist in selecting patients at highest risk for recurrence and perhaps most likely to benefit from additional therapies.

The current study by Nomori and colleagues ${ }^{9}$ is a welcome addition to the growing experience of the sentinel node mapping technique. Their results confirm the promise of this staging tool to assist in giving patients the most precise information about their disease and aid in the identification of those most likely to benefit from future adjuvant therapies. These findings await broader application in resectable lung cancer to refine the sentinel node mapping technique and patient selection criteria.

\section{Reference}

1. Keller SM, Adak S, Wagner H, Johnson DH. Mediastinal lymph node dissection improves survival in patients with stages II and IIIa nonsmall cell lung cancer. Eastern Cooperative Oncology Group. Ann Thorac Surg. 2000;70:358-65.

2. Bollen EC, van Duin CJ, Theunissen PH, vt Hof-Grootenboer BE, Blijham GH. Mediastinal lymph node dissection in resected lung cancer: morbidity and accuracy of staging. Ann Thorac Surg. 1993; 55:961-6.

3. Naruke T, Suemasu K, Ishikawa S. Lymph node mapping and curability at various levels of metastasis in resected lung cancer. $J$ Thorac Cardiovasc Surg. 1978;76:832-39.

4. Kubuschock B, Passlick B, Izbicki JR, Thetter O, Pantel K. Disseminated tumor cells in lymph nodes as a determinant for survival in surgically resected non-small cell lung cancer. J Clin Oncol. 1999; $17: 19-24$. 
5. Perez-Cardona JH, Ordonez NG, Fossella FV. Lymph node micrometastases in non-small cell lung cancer: clinical applications. Clin Lung Cancer. 2000;2:116-20

6. Liptay MJ, Masters GA, Winchester DJ, Edelman BL, Garrido BJ, Hirschtritt TR, et al. Intraoperative radioisotope sentinel lymph node mapping in non-small cell lung cancer. Ann Thorac Surg. 2000;70: 384-9.

7. Liptay MJ, Grondin SC, Pozdol C, Carson D, Knop C, Masters GA, et al. Detection of micrometastases with intraoperative radioisotope sentinel lymph node mapping in non-small cell lung cancer. Proc Am Soc Clin Oncol. 2001;20:313A.

8. Little AG, DeHoyos A, Kirgan DM, Arcomano TR, Murray KD. Intraoperative lymphatic mapping for non-small cell lung cancer: the sentinel node technique. J Thorac Cardiovasc Surg. 1999;117:220-34.
9. Nomori H, Horio H, Naruke T, Suemasu K, Orikasa H, Yamazaki K. Use of technetium TC $99 \mathrm{~m}$ tin colloid for sentinel lymph node identification in non-small cell lung cancer. J Thorac Cardiovasc Surg. 2002;124:486-92.

10. Yoshino I, Yokoyama H, Yano T, Ueda T, Takai E, Mizutani K, et al. Skip metastasis to the mediastinal lymph nodes in non-small cell lung cancer. Ann Thorac Surg. 1996;62:1021-5.

11. Andre F, Grunenwald D, Pignon JP, Dujon A, Pujol JL, Brichon PY, et al. Survival of patients with resected N2 non-small cell lung cancer: evidence for a subclassification and implications. J Clin Oncol. 2000; 18:2981-9.

12. D'Amico TA, Aloia TA, Moore MB, Herndon JE, Brooks KR, Lau $\mathrm{CL}$, et al. Molecular biologic substaging of stage I lung cancer according to gender and histology. Ann Thorac Surg. 2000;69:882-6.

\section{ON THE MOVE?}

Don't miss a single issue of the journal! To ensure prompt service when you change your address, please photocopy and complete the form below.

Please send your change of address notification at least six weeks before your move to ensure continued service. We regret we cannot guarantee replacement of issues missed due to late notification.

\section{JOURNAL TITLE:}

Fill in the title of the journal here.

\section{OLD ADDRESS:}

Affix the address label from a recent issue of the journal here.

\section{NEW ADDRESS:}

Clearly print your new address here.

Name

Address

City/State/ZIP
COPY AND MAIL THIS FORM TO:

Mosby

Subscription Customer Service

6277 Sea Harbor Dr

Orlando, FL 32887
OR FAX TO:

407-363-9661

Mosby
OR PHONE:

800-654-2452

Outside the U.S., call

407-345-4000 